\title{
References:
}

1. Douglas-Scott, S. (2006). A tale of two courts: Luxembourg, Strasbourg and the growing European human rights acquis. Common Market Law Review, vol. 43, issue 3, pp. 629-665.

2. Falalieieva, L. H. (2017). Pryiednannia Yevropejs'koho Soiuzu do Konventsii z prav liudyny: pravova pozytsiia Sudu. [Accession of the European Union to the Convention on Human Rights: the legal position of the Court]. Sudova apeliatsiia, no 3, pp. 151-161.

3. Lenaerts, K. (2018). Speech of the President of the Court of Justice of the European Union, opening of the judicial year, 26 January 2018. Annual report 2018 - European Court of Human Rights, pp. 23-35.

4. Costa, J.P. (2008). The Relationship between the European Convention on Human Rights and European Union Law - A Jurisprudential Dialogue between the European Court of Human Rights and the European Court of Justice. Lecture at the King's College (Inner Temple). London, 7 October 2008, pp. 1-10.

5. Ispolinov, A. S. (2012). Poisk balansa mezhdu svobodami vnutrennieho rynka i pravami chieloveka $\mathrm{v}$ sudiebnoj praktyke ES [Finding a balance between domestic market freedoms and human rights in the EU judicial practice]. Zhurnal zarubiezhnoho zakonodatel'stva i sravnitel'noho pravovedeniia, no 6, pp. 38-49. (in Russian)

\section{THE IDENTIFICATION OF A LAWYER WITH A CLIENT THROUGH THE PRISM OF VIOLATIONS OF OTHER GUARANTEES OF THE PRACTICE OF LAW}

\author{
Ruslan Skrynkovskyy ${ }^{1}$ \\ Lyubomyr Sopilnyk ${ }^{2}$ \\ Rostyslav Sopilnyk ${ }^{3}$
}

DOI: https://doi.org/10.30525/978-9934-588-11-2_63

According to Art. 23 of the Law of Ukraine «On the Bar and Practice of Law» (as of 05.07.2012, № 5076-VI) [1], the professional rights of the lawyer, his honour and dignity are guaranteed and protected by the current Constitution of Ukraine [2], this Law [1] and other applicable laws of Ukraine, in particular: 1) interference with the activity of a lawyer, including any possible obstacles to the practice of a lawyer, is prohibited; 2) it is forbidden to insist and demand (require) a lawyer to disclose any information (documents) that are advocate secrets [3];3) it is forbidden to interfere with the legal position of the lawyer, in private (personal) communication between the lawyer and the client, as well as to identify the lawyer with the client [1].

Given the above, it should also be noted that, in recent years, in Ukraine, in view of the political circumstances, lawyers have to defend those guilty of forced crackdown of Euromaidan, persons involved in resonant crimes against members of the Revolution of Dignity, as well as represent different parties in court, in particular,

\footnotetext{
${ }^{1}$ Lviv University of Business and Law, Ukraine

${ }^{2}$ Lviv University of Business and Law, Ukraine

${ }^{3}$ Lviv University of Business and Law, Ukraine
} 
persons to whom the provisions of the Law «On Purification of Power» (as of 16.09.2014 № 1682-VII) apply [4], terrorists and separatists, deputies of different levels, and persons subject to public condemnation [5].

In the context of this (as a result of the analysis of the Report of the Ukrainian National Bar Association (UNBA) on the violation of the rights of lawyers and guarantees of the practice of law in Ukraine for 2013-2018 [5]), it is found that today the identification of lawyers with clients takes place not only from the side of people and citizens of Ukraine or the media but also by some investigators, prosecutors, and judges in some cases, who are rather disrespectful to the lawyers who protect the aforementioned persons.

Given this situation, lawyers and legal specialists (experts) emphasize that the Law of Ukraine «On the Bar and Practice of Law» [1] prohibits identifying a lawyer with a client, that investigators, prosecutors, and judges must respect the rights of lawyers and also treat their clients with tolerance and in no way allow the violation of fundamental human rights and freedoms in accordance with the Constitution of Ukraine [2].

At the same time, it is determined that the identification of a lawyer with a client by pre-trial investigation body leads to the violation of other guarantees of the practice of law [5] established by the Law of Ukraine «On the Bar and Practice of Law» [1]. To confirm this statement, let us consider the real situations in this direction.

Thus, the UNBA Report for 2013-2018 [5] states that the provision of professional legal assistance to such clients (the above persons) by some investigators is regarded as the complicity of a lawyer in a crime. This results in that they summon a lawyer for questioning as a witness and in some cases even declare the lawyer suspected of committing a crime. In addition, it is found that in some (individual) cases, investigators also initiate searches of office premises or inspection of housing, other possession of a lawyer and, on the pretext of obtaining evidence of «criminal activity,» withdraw specific documents directly related to the lawyer's activities [5]. Against this background, the professional advocacy community emphasizes the problem of violations of lawyers' rights and guarantees of the practice of law in Ukraine.

Hence the important question: how to comply with the law and what should lawyers do in such cases? And we can also conclude: in the system of providing guarantees of the practice of law in Ukraine, the prohibition of identifying a lawyer with a client is one of the main and important guarantees of a lawyer's professional activity.

\section{References:}

1. Pro advokaturu ta advokatsku diialnist: Zakon Ukrainy vid 05.07.2012 r. № 5076-VI (iz zminamy ta dopovnenniamy). Retrieved May 1, 2019, from http://zakon5.rada.gov.ua/laws/ show/5076-17 (in Ukrainian)

2. Konstytutsiia Ukrainy [The Constitution of Ukraine]. Zakon Ukrainy No. 254к/96-BP, 28 June 1996. Retrieved April 1, 2019, from http://zakon.rada.gov.ua/laws/show/254к/96-вр (in Ukrainian) 
3. Antoniuk, S. A. (2019). Pro advokatsku taiemnytsiu. Aktualni problemy suchasnoi nauky [Actual Problems of Modern Science]: Abstracts of scientific papers XLI International scientificpractical conference (Kharkiv - Viden - Berlin, 30 May 2019) / Mizhnarodnyi naukovyi tsentr rozvytku nauky i tekhnolohii, P. 78-80. doi: http://doi.org/10.5281/zenodo.3263843 (in Ukrainian)

4. Pro ochyshchennia vlady: Zakon Ukrainy vid 16.09.2014 r. № 1682-VII (iz zminamy ta dopovnenniamy). Retrieved May 1, 2019, from https://zakon.rada.gov.ua/laws/show/1682-18 (in Ukrainian)

5. Zvit pro porushennia prav advokativ ta harantii advokatskoi diialnosti v Ukraini za 2013-2018 rr. Kyiv: Natsionalna asotsiatsiia advokativ Ukrainy. 2018. 44 p. Retrieved May 1, 2019, from https://unba.org.ua/assets/uploads/news/zvity/UNBA_Zahyst_Adv_2018_UKR_WEB(1).pdf (in Ukrainian) 